\title{
INCREASING THE ROLE OF ZAKAT INSTITUTIONS IN POVERTY REDUCTION THROUGH PRODUCTIVE ZAKAT PROGRAMS IN INDONESIA
}

\author{
Sutrisno $^{1 *}$, Razali Haron ${ }^{2}$
}

${ }^{1 *}$ Department of Islamic Economics Faculty of Islamic Studies, Universitas Muhammadiyah Yogyakarta, Indonesia;

${ }^{2}$ IIUM Institute of Islamic Banking and Finance (II $\left.i \mathrm{BF}\right)$, International Islamic University, Malaysia. Email: ${ }^{1 *}$ sutrysno@umy.ac.id, ${ }^{2}$ hrazali@iium.edu.my

Article History: Received on $03^{\text {rd }}$ April 2020, Revised on $28^{\text {th }}$ May 2020, Published on $26^{\text {th }}$ June 2020

\begin{abstract}
Purpose of the study: The aim of this study is to identify zakat programs that have been implemented by zakat institutions in the context of increasing social roles, especially to reduce poverty. This study concludes that a strategic program in the distribution of zakat to help the poor improve their welfare.
\end{abstract}

Methodology: This study adopts a document analysis approach involving a series of systematic steps to review the research documents with the checking of data, interpreting them to get a deep understanding, obtaining the meaning contained, and scientific development in research.

Main Findings: The implementation of the productive zakat program carried out by zakat institutions in Indonesia can reduce poverty. Almost all the funds' distribution programs carried out by zakat institutions run smoothly and have been proven to reduce poverty. The recipients of zakat who participated in the productive zakat program also showed an increment in their welfare.

Applications: Zakat institutions in Indonesia can adopt productive zakat programs to reduce poverty. Besides, zakat institutions can increase their role in improving the welfare of the poor. On the other hand, the role of empowerment, primarily through the productive zakat program, can be applied in all zakat institutions in Indonesia.

Novelty/Originality: The productive zakat program can be used as a model by the government as a means to improve the welfare of the community. Furthermore, the role of the zakat institution as a representative of the implementation of social care will increasingly be felt by the community, especially the needy recipients of zakat.

Keywords: Zakat Institutions, Poverty Reduction, Productive Zakat Programs, Zakat Distribution, Zakat Recipient.

\section{INTRODUCTION}

Paying zakat is mandatory for Muslim society as mentioned in the Qur'an (At-Taubah verse 103) which means "Take charities from their wealth, that you may purify them and cleanse them thereby, and pray for them. Surely your prayer is a source of tranquillity to them. And Allah is All-Hearing, All-Knowing ('Ali, 2015). Zakat is one of the five pillars of Islam apart from performing the prayers and fasting that all Muslims should implement in their daily life. With regard to Indonesia, the country regulated its zakat management through Law 23 Year 2011 which includes zakat collection, zakat management, and zakat distribution to zakat recipients (mustahik) for the benefit of the society (ummah) being the purpose of the zakat as stated in the 1945 Constitution of Indonesia. However, the implementation of management, collection, and distribution of zakat still face several obstacles as reported by the National Board of Zakat in the 2018 annual report the collection of new zakat reached 6.2 trillion Rupiah or 1.3\% of Indonesia's potential collection estimated at 462 trillion Rupiah per year (BAZNAS, 2019).

BAZNAS (2018) reported that the possibility of zakat funds managed by zakat institutions throughout Indonesia could not reach $2 \%$ of the potential yearly collection. Up to 2019, 16 formal zakat institutions received licenses from the government including Badan Amil Zakat Nasional (BAZNAS) being the parent of zakat institutions owned by the government. On the other hand, empowerment programs to alleviate poverty have not been carried out at the maximum by the existing zakat institutions. The BAZNAS annual report (BAZNAS, 2019) shows that the entire zakat institution that carries out a productive economic empowerment program only reaches $30 \%$ of the total funding channelled by zakat institutions throughout Indonesia. Moreover, zakat management carried out by zakat institutions in Indonesia is still far from the expectation. Some of the obstacles facing zakat institutions as reported by BAZNAS include the lack of awareness of zakat payers, the scarcity of zakat management resources and sanctions or consequences of those who do not pay zakat have not received penalties (BAZNAS, 2017).

The distribution of zakat funds is carried out by various zakat institutions in Indonesia through many programs that are generally in accordance with the National Zakat Report (BAZNAS, 2019) covering the fields of education, health, humanity, advocacy, and economic affairs. In this study, we examine the productive zakat programs conducted by zakat institutions in Indonesia. This study looks into the reality of the programs created by the zakat institutions and its role in alleviating poverty in Indonesia and establishes the relationship between productive zakat programs and poverty alleviation, at the same time promotes the role of zakat institutions at the local and international level. This study adopts 
the qualitative approach using document analysis following Bowen (2009), Eldersevi and Haron (2020), and Nomran and Haron (2020).

The term productive zakat means that the zakat recipients can and will use the fund to set up a new business or develop the existing business to deliver greater benefits (Asnaini, 2008). Funds received are not spent for daily consumption but are developed and used to assist the operations of the business, so that they can grow further to improve their standard of living.

The principle of zakat management was pursuant to the Zakat Law 2011 (Articles 2 \& 3) that zakat management is based on Islamic law, trust, expediency, justice, legal certainty, integration and accountability. The goal of managing zakat is to increase the efficiency and effectiveness of services in zakat management, to increase the benefits of zakat for the achievement of community welfare and poverty alleviation (Presiden Republik Indonesia, 2011).

The implementation of zakat management is further regulated in the Government Regulation (Rule No. 14 Year 2014), namely the organization of the functions of zakat planning, implementation, distribution, use, control, and reporting. In addition, the regulation is a measure of the assessment of the management process carried out by the zakat institution as a form of accountability to zakat payers (muzakki), zakat recipients (mustahik), the community and the government as an assessment to strengthen the benefits of zakat in Indonesia (PeraturanPemerintahRepublik Indonesia, 2014).

The study of the implementation of the measurement of the National Zakat Index (IZN) in all 34 provinces in Indonesia showed that mostly the implementation is in the fairly good category with $65 \%$ rate. While the remaining $2 \%$ is not good and $33 \%$ are still in the assessment process. Furthermore, the provincial performance assessment can be divided into two categories. First, provinces with a high score because of the large micro dimension index value and this constitutes $89.3 \%$ of the total provinces while the remaining $10.7 \%$ has a higher macro index value than the micro index. It can be concluded that the performance of zakat management by the zakat institutions in Indonesia based on the IZN to be favourable (DevisiRisetdanKajian Zakat Nasional Indonesia, 2017).

The main objective of this study is to deepen the discussion on the role of the zakat institution in alleviating poverty through the productive zakat programs in Indonesia. Moreover, research conducted by BAZNAS (BAZNAS, 2019) indicates that the role of the zakat institution can be further enhanced by increasing the productive zakat program with the economic empowerment on the zakat recipients. In addition, this study is organized into five main sections. The introductory part includes a discussion of the role of the zakat institutions in Indonesia and its role in alleviating poverty. Section 2 provides a literature review of the productive zakat program. The research method of this study is set out in Section 3. The review of the productive zakat program that has been implemented and its problems and solutions are explained in Section 4, and the conclusions and recommendations for future research are in section 5.

\section{LITERATURE REVIEW}

Ali (2014) explains that the integration of Islamic microfinance is a significant consideration for developing countries in alleviating poverty, including countries with a majority Muslim population to increase the overall economic development. Zakat and waqf are believed to be the tools to create economic stability by having the right distribution of funds to people in need. According to the Islamic principles, microfinance covers the overall economic and financial aspects by providing a variety of tools used as models that can bridge the gap between the poor and the rich.

In 2016, a study carried out by Nizar indicating that the model of distributing zakat, infaq, and shadaqah productively can be achieved and provides good economic impact and welfare by providing business capital that is not directly used up by zakat recipients (mustahik). The distribution of productive zakat funds in the Syarif Hidayatullah Mosque for an example is considered to be quite an effective model to reduce poverty in the coral reef area of Ploso Malang, Indonesia. Furthermore, this study provides empirical evidence that mosques can act as mediators in distributing zakat to improve the welfare of mustahik around the area. Nevertheless, the study concludes that the implementation of the fund distribution program has not been carried out systematically and further improvement is necessary for future programs.

Beikand Pratama (2016) found that the productive zakat fund program provided by Dompet Dhuafa (an Islamic philanthropy institution that manages funds from zakat, infaq, alms, endowments and other halal funds that are devoted to empowering the poor) can increase the income of the mustahik. This program can also free mustahik from poverty. The average revenue obtained by mustahik increased by 147.14 percent after participating in the proposed program and succeeded in reducing the poverty rate among the mustahik. The study also reported that the index of the welfare of zakat recipients increased by 63.7 percent. Therefore, a productive-based zakat fund distribution program needs to be adopted as an integration of poverty alleviation programs by the government and private zakat institutions because it can reduce poverty among mustahik.

Nurzaman et al. (2017) showed that the zakat program had run quite effectively in increasing the welfare index of mustahik both in material and spiritual aspects in western Indonesia. This was shown by the increase in mustahik welfare from $7 \%$ to $47 \%$, and the average monthly income has increased from $19 \%$ to $119 \%$. On the other hand, the level of material poverty, spiritual poverty, and absolute poverty has also declined. The productive zakat program has been effective even though the study did not measure the zakat program in the form of a mustahik productive enterprise. The 
results of their study show that the success of empowering mustahik were by the intensity of coaching and monitoring work programs that had been made.

Mayes et al. (2017) report that the productive zakat empowerment dominated by mustahik with the age of 31-45 years reached 64.6 percent in their studies in Rokan Hulu Regency, Riau. In addition, 81.5 percent of the mustahik stated that the productive zakat program had a good impact on them while 3.1 percent of the total respondents reported it as very good. On the other hand, it can be concluded that even though the zakat funds collected are relatively small, they have a real impact on poverty alleviation through the productive zakat programme. In addition, zakat is an effective financial instrument to act as the capital of poor people and this was concluded by the headcount ratio represents the number of poor mustahik, showing a decreased by $0.7 \%$. Moreover, the study also reported that the poverty depth index also decreased by 1.3 percent. Thus the study concludes that zakat, therefore, is the right instrument for empowering the poor.

Maulidaand Rahmatullah (2018) concluded that the implementation of the zakat village index by the provision of productive zakat programs was categorized as having a reasonably significant impact on poverty alleviation in South Kalimantan. In addition, the study can be a reference for zakat institutions with the implementation of productive zakat programs in the form of cattle and goat farms that can improve the development of quality agriculture and increase the welfare of zakat recipients. The study proves that the implementation of productive zakat programs can alleviate poverty.

According to Ayyubiand Saputri (2018), the distribution and the empowerment program of Baitul Maal (treasury) of the Jogokariyan Mosque, Yogyakarta has contributed to the reduction in poverty among the mustahik and improved their material and spiritual well-being. This is evidenced based on the reduction in the poverty index using the CIBEST model. The distribution of aid in the zakat program includes providing basic food needs, educational scholarships, medical service support, assistance for a debt-strapped household, accommodation for travellers who run out of money and volunteering in disasters. The study concludes that a well-managed zakat institution (mosque) is proven to reduce poverty and improve the welfare of mustahik.

Rustyani and Rosyidi (2018) employed the efficiency methodology and reported that the overall productivity of the zakat institutions in Indonesia has increased during the period 2014 -2016. The study shows that $67 \%$ of the institution has recorded higher productivity, while the remaining 33\% experienced lower productivity. The study concludes that zakat institutions can, therefore manage the zakat program to assist zakat recipients in reducing poverty.

Sukesti and Budiman (2018) provide empirical evidence that a productive zakat program can improve growth, benefits and business development for small and medium-sized enterprises (SMEs) in Semarang, Central Java. Moreover, zakat enables SMEs to operate at its best and achieving good results. In contrast to zakat paid directly to individual zakat recipients, the zakat management program collected by amil (one who is appointed to collect zakat) has substantially reduced the poverty rate of the community. Thus, a productive zakat program is not only for zakat recipients to reach ends meets but also to boost their social welfare.

Suprayitno (2019) studied the impact of zakat distribution on economy, consumption, and investment in Malaysia. The study found significant evidence that zakat positively influences economic growth, consumption and investment, both in the short and long term. The study, therefore, proposed that the management of zakat in Malaysia can be referred to as a best practice model by other countries to reduce the poverty of zakat recipients.

Mahfuzha et al. (2019) examined the effect of zakat on economic growth in four countries in South East Asia, including Indonesia, Malaysia, Brunei Darussalam, and Singapore, over a period of six years from 2010 to 2015. The study concludes that zakat has a significant positive effect on the economic growth of the countries. Despite that, due to zakat that being disbursed once a year coupled with the small amount of funds administered by the zakat institutions in the sampled countries, the impact of zakat on poverty reduction is still minimal.

\section{METHODOLOGY}

This study adopts a document analysis approach involving a series of systematic steps to review documents and analyze research results that are already available both in printed and electronic form. The stages involved examining data, interpreting it to gain an in-depth understanding, obtaining the meaning contained and scientific development in research (Bowen, 2009; Eldersevi \&Haron, 2020; Nomran \& Haron, 2020).

The data that were used for this study was taken from various sources including relevant journals, related books, newspapers, advertisements originated from print and electronic media, official broadcasts, scientific articles, activity program proposals, official forms, material summaries, program manuscripts from radio and television, official organization reports, survey data, and various other official public data.

An analytical procedure adopted in this study includes the discovery, the selection, the assessment, and the synthesis of the data contained in the document. Specifically, this study classifies research reports from various sources related to the implementation of the productive zakat programs carried out by the zakat institutions, including those derived from the results of BAZNAS in the 26 provinces throughout Indonesia. 


\section{DISCUSSION AND ANALYSIS}

\section{Establishment of zakat institutions in Indonesia and the general role of zakat institutions}

Zakat has been known to the people of Indonesia since the 13th century when Islam was introduced into the country by traders. Zakat was popularly carried out among the community such as rice, money, or staple food paid to clerics (kiai) who are in their community. Moreover, the kiai channelled zakat to Islamic boarding schools, mosques, and social care institutions. Other modes of distribution are carried out by distributing directly to the poor, needy or mustahik (zakat recipients). In addition, zakat collections (zakat fitrah) are carried out during the month of Ramadhan before the Eid (festival) prayer. The management of zakat is carried out individually on behalf of boarding schools and mosques to be managed and channelled to the local community (Fatwa et al., 2004).

The initiation of the management of zakat on an institutional basis started by the Muslim communities at the national level through the delegation of eleven scholars who submitted a proposal to the President Suharto on September 24, 1968, at the State Palace. Following this, the government established a formal zakat management institution in the capital city of Jakarta under the name Badan Amil Zakat Infaq/Shadaqah (BAZIS). In 2011 the government established the Zakat Law (No. 23 of Year 2011) as the basis for managing and distributing zakat funds for all zakat institutions in Indonesia. In 2019 there were 16 national-level zakat institutions that obtained permission from the Ministry of Religion to control and channel zakat funds directly to the recipients of zakat (Jaelani, 2015).

The role of zakat institutions, in general, has been mandated by the Zakat Law (No. 23 Year 2011, Article 1), stating that zakat management is an activity that involves planning, implementing, and coordinating the collection, distribution and the utilization of zakat. The purpose of zakat management as regulated in the Article 3of Zakat Law (No. 23 of the Year 2011 ) is to improve the effectiveness and the efficiency of zakat management and to increase zakat benefit concerning public welfare and poverty reduction (PresidenRepublik Indonesia, 2011).

Zakat institution is divided into two categories in carrying out its role (Article 17 of Zakat Law), which are the National Amil Zakat Agency (BAZNAS) and the Amil Zakat Institution (LAZ). BAZNAS is a government-run zakat institution consisting of the intermediate level in the national capital, provinces, city, and rural districts throughout Indonesia. LAZ is a zakat institution managed by community groups and socio-religious organizations that are legally established and obtain permission from the government through the Ministry of Religion of the Republic of Indonesia to conduct zakat activities. All zakat institutions in Indonesia are required to comply with the zakat law and regulations that have been set by the government in order to carry out their operational roles (PeraturanPemerintahRepublik Indonesia, 2014).

\section{The specific role of zakat institutions in poverty alleviation}

The zakat management during the Prophet Muhammad's (PBUH) life was carried out institutionally by giving a broader meaning to the word 'amilin' which refers to a state institution or a government as a formal zakat manager. In the hadith of Bukhari and Muslim from Abu Huraira (r.a.), the Messenger of Allah appointed Ibn Lutbiahas representative (amil) to collect zakat from the eligible Muslims. The command of management of zakat was also exemplified during the time of the Prophet (PBUH) when the Prophet (PBUH) sentMuadz Bin Jabal to Yemen for zakat collection from the rich and to be managed and distributed to the poor as recipients of zakat (Hafidhuddin, 2006).

The role of institutions in managing zakat was applied in Indonesia since the establishment of zakat institution in 1968. The zakat management institution is mentioned in the Zakat Law (Article 3 Year 2011) which ordered that the management of zakat to realize public welfare and poverty alleviation. In addition, zakat institution must have four institutional standards in carrying out their functions to manage zakat. First, zakat institutions must be trustworthy in managing zakat funds. Second, professionalism among zakat managers in managing the zakat. Third, transparency in managing zakat funds, collecting and distributing to zakat recipients. Fourth, skilled management of zakat in implementing, evaluating, and monitoring the zakat program to create more advanced zakat institutions (Nadzri et al., 2012).

The distribution of zakat for enterprise to mustahik is evaluated in terms of potential assessment, capacity building, business asset distribution, and assistance. In the evaluation process, the business potential of zakat recipient is identified. Moreover, the distribution of zakat for productive businesses is expected to be more effective and efficient. The re-distribution of business assets is an essential pillar in the productive zakat agenda. It is expected that mustahik has a good business capacity in this zakat program. Finally, assistance becomes a vital agenda in the distribution of productive zakat program to obtain the results of capacity building and re-distribution of business asset management to achieve the goal of increasing business capacity in the assisted mustahik (Asnaini, 2008).

According to Amiruddin (2015), the management of zakat in Muslim countries specifically can be categorized into three models. First, the state requires zakat to its citizens, and its implementation is managed by the state. Second, the state does not impose zakat on its citizens but is left to the awareness of each individual. Third, the zakat management model involving the state as well as the private sector (community) in managing zakat as in Indonesia. Moreover, zakat empowerment for productive enterprises is permitted by Islamic law if the zakat funds are sufficient for distribution and application must be submitted to competent, professional, and trustworthy zakat institutions and followed by the supervision and guidance from the institutions (Tahir and Triantini, 2015). 
The distribution of productive zakat is required to go through the identification process, including potential assessment, capacity building, asset reform, and assistance. This stage is carried out to maximize the distribution of productive zakat funds. The main objective of the productive zakat distribution program is to increase the business capacity of zakat recipients (Wahid, 2016).

Zakat institutions can improve zakat recipients' well-being through productive zakat programs. According to Wahab et al. (2016), the findings on productive zakat programs derived from the different regions in Indonesia are relatively diverse, due to differences in the social, economic, and cultural aspects of mustahik in a particular area. Furthermore, several factors can be the important determinants for the success of the programs such as the intensity of coaching and monitoring of the programs. The distribution of zakat funds in the form of either cash and commodity like cattle, fertilizer, seeds, or a combination of cash and commodity is done to fulfill the needs of mustahik to establish or expand their businesses.

\section{An overview of the practices of the productive zakat program}

Hidajat (2017) studied the implementation of productive zakat management in improving the economy of the people on the island of Makassar, Indonesia. The implementation of a productive zakat program involves implementing the management function of the mustahik program, planning model, organizing and division of tasks and supervision. The study found that a productive zakat program carried out by the zakat institution in Makassar is able to increase the welfare of mustahik and improve their entrepreneurship skills.

Mujiatun (2018) concluded that zakat has a great potential as an effective means to empower the people's economy and alleviate poverty by providing effective and efficient zakat management, legal certainty, and legislation. In addition, zakat management is based on Shariah principles, trust, benefits, justice, integrated, and accountability. Thus, zakat management institution should maximize their role in economic empowerment and poverty alleviation to communities.

Mayes et al. (2017) in their survey reported that $81.5 \%$ of the respondents stated that the productive zakat program had run quite well and as many as $3.1 \%$ stated it to be very well. The study concludes that even though zakat funds are not collected at the maximum, they have a real impact in alleviating poverty. Zakat hence is proven to be the right instrument in empowering the poor.

Despite the implementation of productive zakat programs that have been running effectively and can significantly improve the welfare of the poor, efforts are needed by all Muslims, including the government, zakat management institutions, and other societies in Indonesia to develop zakat according to their potential, so that zakat can be utilized according to its function. In addition, in order to achieve the goal of increasing mustahik business independence, it is necessary to have an efficiently targeted program carried out by the zakat institutions. This can be done by assisting in the management of mustahik business funds so that funds managed by mustahik will increase the welfare and lead them out of poverty and eventually to become zakat payers (muzakki) (Adachi, 2018).

Table 1: Number of Mustahik (Zakat Recipients) based on Sectors (2017 and 2018).

\begin{tabular}{lll}
\hline Years & $\mathbf{2 0 1 7}$ & $\mathbf{2 0 1 8}$ \\
\hline Education & $1,088,758$ & $1,415,385$ \\
\hline Health & $1,544,611$ & $2,007,994$ \\
\hline Humanity & $3,980,188$ & $5,174,244$ \\
\hline Economy & 365,829 & 475,578 \\
\hline Da'wah-Advocacy & $1,753,646$ & $2,279,740$ \\
\hline TOTAL & $\mathbf{8 , 7 3 3 , 0 3 2}$ & $\mathbf{1 1 , 3 5 2 , 9 4 2}$ \\
\hline
\end{tabular}

Source: BAZNAS Outlook 2019 (page 52), data until December 2018

Based on the data in Table 1 above, the number of beneficiaries in 2017 reached 8,733,032. The most beneficiaries is in the humanitarian field which is 3,980,188. While the lowest beneficiaries are in the economy with 365,829 . The projection of the highest number of beneficiaries in 2018 is in the humanitarian sector, which accounts for 5,174,244 while the lowest is in the economy which is 475,578 (BAZNAS, 2019).

Rustyani and Rosyidi(2018) reported that there is a positive influence between the utilization of productive zakat on the rolling-stock program and the welfare of mustahik in the Gresik regency, East Java province of Indonesia. Mustahik welfare is significantly improved in terms of income development and the fulfillment of mustahik needs after participating in the productive zakat utilization program through the rolling-cattle program. The study proposes that zakat management institutions should be able to maximize the use of productive zakat in the future both in terms of implementation and data archiving so that it will be easier for audits, research, and evaluation of program development. In addition, the study suggests that for the rolling-cattle program to focus more on the growth of live stocks with fattening and high in calories patterns, as this pattern can bring faster benefits or results to the recipients. 
Table 2: Impact of Productive Zakat based on Poverty Index in Indonesia (Provinces)

\begin{tabular}{|c|c|c|c|c|c|}
\hline No & Name of Province & Before Program & After Program & $\Delta$ & Poverty index \\
\hline 1 & Aceh & 0.250 & 0.110 & -0.137 & $\downarrow$ \\
\hline 2 & Bali & 0.400 & 0.280 & -0.115 & $\downarrow$ \\
\hline 3 & Bangka Balitung & 0.550 & 0.530 & -0.022 & $\downarrow$ \\
\hline 4 & Banten & 0.410 & 0.200 & -0.211 & $\downarrow$ \\
\hline 5 & Bengkulu & 0.220 & 0.040 & -0.173 & $\downarrow$ \\
\hline 6 & DIY & 0.370 & 0.280 & -0.092 & $\downarrow$ \\
\hline 7 & Gorontalo & 0.670 & 0.430 & -0.235 & $\downarrow$ \\
\hline 8 & Jambi & 0.180 & 0.050 & -0.129 & $\downarrow$ \\
\hline 9 & Jawa Barat & 0.200 & 0.160 & -0.039 & $\downarrow$ \\
\hline 10 & Jawa Tengah & 0.180 & 0.050 & -0.129 & $\downarrow$ \\
\hline 11 & JawaTimur & 0.240 & 0.240 & -0.001 & $\downarrow$ \\
\hline 12 & Kalimantan Barat & 0.190 & 0.140 & -0.050 & $\downarrow$ \\
\hline 13 & Kalimantan Selatan & 0.070 & 0.040 & -0.037 & $\downarrow$ \\
\hline 14 & Kalimantan Tengah & 0.120 & 0.070 & -0.056 & $\downarrow$ \\
\hline 15 & Kalimantan Timur & 0.150 & 0.060 & -0.090 & $\downarrow$ \\
\hline 16 & Kalimantan Utara & 0.060 & 0.030 & -0.026 & $\downarrow$ \\
\hline 17 & Kepulauan Riau & 0.120 & 0.060 & -0.062 & $\downarrow$ \\
\hline 18 & NTB & 0.250 & 0.260 & +0.013 & $\uparrow$ \\
\hline 19 & NTT & 0.270 & 0.130 & -0.148 & $\downarrow$ \\
\hline 20 & Papua Barat & 0.090 & 0.010 & -0.073 & $\downarrow$ \\
\hline 21 & Riau & 0.120 & 0.030 & -0.087 & $\downarrow$ \\
\hline 22 & Sulawesi Tengah & 0.210 & 0.170 & -0.034 & $\downarrow$ \\
\hline 23 & Sulawesi Tenggara & 0.400 & 0.280 & -0.115 & $\downarrow$ \\
\hline 24 & Sumatera Barat & 0.210 & 0.070 & -0.146 & $\downarrow$ \\
\hline 25 & Sumatera Selatan & 0.210 & 0.020 & -0.197 & $\downarrow$ \\
\hline \multirow[t]{2}{*}{26} & Sumatera Utara & 0.200 & 0.080 & -0.115 & $\downarrow$ \\
\hline & National & 0.240 & 0.190 & -0.054 & $\downarrow$ \\
\hline
\end{tabular}

Source: BAZNAS Strategic Study Center of the Republic of Indonesia (November 21, 2018)

Based on Table 2 above, the severity of poverty based on the Poverty Index by BAZNAS (2018) shows a decline in almost all provinces after zakat recipients obtaining productive zakat assistance except in the West Nusa Tenggara (NTB) which recorded an increase by 0.013 . The highest drop in poverty (0.235) occurred in Gorontalo province (Sulawesi) with an initial value of 0.67 to become 0.43 after mustahik obtaining zakat assistance. The statistics show that almost all provinces benefited from the productive zakat empowerment programs by having lower poverty compared to before the programs were undertaken.

\section{CONCLUSION AND RECOMMENDATIONS FOR FUTURE RESEARCH}

The implementation of a productive zakat program carried out by zakat institutions in Indonesia can reduce poverty. This study provides evidence through document analysis that the overall fund distribution program carried out by the zakat institutions reduced the poverty rate of zakat recipients. Moreover, the zakat recipients who participated in the productive zakat programs also showed an increment in their welfare.

Several recommendations can be put forward in this study. First, the zakat institutions both the government and the private institutions should create more effective productive zakat programs to reduce poverty in Indonesia as such programs can reduce poverty and improve the welfare of the poor. Second, future research should focus on productive zakat programs from the perspective of planning, implementation and evaluation of the fund distribution to improve the quality of the program implementation, hence reducing the poverty rate more significantly. The scope of future studies on the role of the zakat institutions can be specifically undertaken to improve the well-being of the community as well as small and medium enterprises through empowerment programmes. Moreover, research can be carried out to study the role of zakat institutions as part of the Sustainable Development Goals (SDGs).

\section{ACKNOWLEDGMENT}

We would like to thank Muhammadiyah University of Yogyakarta for the financial assistance in completing this paper. Our gratitude also goes to the Faculty of Islamic Economics at the Muhammadiyah University of Yogyakarta for allowing us to present this paper in the International Conference on Islamic Studies in the Digital Era (ICOSI-ICISDE). 


\section{AUTHORS CONTRIBUTION}

This paper was written and planned by Sutrisno. Razali Haron and Sutrisno carried out the data collection, analyses and the discussion of the results of this study.

\section{REFERENCES}

1. Adachi. M. (2018). Discourses of Institutionalization of Zakat Management System in Contemporary Indonesia : Effect of the Revitalization of Islamic Economics. International Journal of Zakat, 3(1), 23-35. https://doi.org/10.37706/ijaz.v3i1.71

2. 'Ali, M.S. (2015). The Holy Qur'an, Arabic Text and English and Translation. Islam International Publications Limited: Surrey, UK.

3. Ali,K. M. (2014). Integrating Zakah, Awqaf and Islamic Microfinance for Poverty Alleviation: Three Models of Islamic Micro Finance. IRTI Working Paper Series for Islamic Research and Training Institute.

4. Amiruddin, K. (2015). Pengelolaan Zakat di Dunia Muslim. Ahkam, 3(1), 139-166. https://doi.org/10.21274/ahkam.2015.3.1.137-164

5. Asnaini. (2008). Zakat ProduktifdalamPerspektifHukum Islam. PustakaPelajar: Yogyakarta.

6. Ayyubi, S. E.\&Saputri. H. E. (2018). Analysis of the Impact of Zakat, Infak and Sadaqah Distribution on Poverty Alleviation Based on the CIBEST Model (Case Study : Jogokariyan Baitul Maal Mosque, Yogyakarta). International Journal of Zakat, 3(2), 85-97. https://doi.org/10.37706/ijaz.v3i2.80

7. BAZNAS. (2017). Annual Report BAZNAS 2017. Retrieved from www.baznas.go.id

8. BAZNAS. (2018). Productive Zakat Impact on the Poverty Index According to Had Kifayah. Retrieved from https://www.puskasbaznas.com/publications/officialnews/875-productive-zakat-impact-on-the-poverty-indexaccording-to-had-kifayah

9. BAZNAS. (2019). Outlook Zakat Indonesia 2019. Retrieved from https://puskasbaznas.com/publications/b ooks/885-outlook-zakat-indonesia-2019

10. Beik, I. S.,\&Pratama, C. (2016). Zakat Impact on Poverty and Welfare of Mustahik: A CIBEST Model Approach. Islamic Finance and Economic Review, 1(1), 1-13. https://doi.org/10.21098/jimf.v1i2.524

11. Bowen. G. A. (2009). Document Analysis as a Qualitative Research Method. Qualitative Research Journal, 9(2), 27-40. https://doi.org/10.3316/QRJ0902027

12. DevisiRisetdanKajian Zakat Nasional Indonesia. (2017). EvaluasiKinerjaPerzakatanNasional. PusatKajianStrategis BASNAS: Jakarta Pusat.

13. Eldersevi, S.,\&Haron, R. (2020). An Analysis of Mașlaḥah Based Resolutions Issued by Bank Negara Malaysia. ISRA International Journal of Islamic Finance, 12(1), EarlyCite. https://doi.org/10.1108/IJIF-092018-0103

14. Fatwa, A.M., Djamal D.M., \& Mufti, A. (2004). Problem Kemiskinan Zakat SebagaiSolusiAlternatif. Belantika: Jakarta Selatan.

15. Hafidhuddin, D. (2006). MembangunPeradaban Zakat MenitiJalanKegemilangan Zakat.InstitutManajemen Zakat: Indonesia.

16. Hidajat, R. (2017). PenerapanManajemen Zakat ProduktifDalamMeningkatkanEkonomiUmat Di Pkpu (PosKeadilanPeduliUmat) Kota Makassar. Millah: JurnalStudi Agama,1(1), 63-84.

17. Jaelani. A. (2015). Manajemen Zakat di Indonesia dan Brunei Darussalam (1st Ed.). Nurjati Press: Cirebon.

18. Mahfuzha, A.,Rizki, C. Z.,Sapha, D.,Fitriyani, F., Jamal, A.,\&Weri, W. (2019). Is Zakat Important in Reducing Poverty?Advances in Social Science, Education and Humanities Research, 292, 558-562. https://doi.org/10.2991/agc-18.2019.83

19. Maulida, S.,\&Rahmatullah, A. (2018). The Implementation of IndeksDesa Zakat (IDZ) for Priority Areas of the Zakat Community Development (ZCD) Program for the Empowerment of Productive Mustahiq in South Kalimantan. International Journal of Zakat, 3(3), 83-99. https://doi.org/10.37706/ijaz.v3i3.99

20. Mayes, A.,Setiawan, D.,Isbah, U.,\&Zuryani, H. (2017). The Role of Productive Zakat for Helping Poor Community in Rokan Hulu Regency (Case Study of National Amil Zakat of Rokan Hulu Regency). International Journal of Finance and Accounting, 6(6), 179-185.

21. Mujiatun, S. (2018). Model of Professional Zakat Management in Indonesia.Kumpulan JurnalDosenUniversitas Muhammadiyah Sumatera Utara, 2(4), 80-90.

22. Nadzri, F. A. A.,AbdRahman, R.,\& Omar, N. (2012). Zakat and Poverty Alleviation: Roles of Zakat Institutions in Malaysia. International Journal of Arts and Commerce, 1(7), 61-72.

23. Nizar, M. (2016). Model PemberdayaanEkonomiMasyarakatMelaluiPengelolaan Zakat, InfaqdanShadaqah (ZIS) di Masjid BesarSyarifHidayatullahKarangploso Malang. Malia,8(1), 41-60.

24. Nomran, N.M., \& Haron, R. (2020). A Systematic Literature Review onShari'ah Governance Mechanism and Firm Performance inIslamic Banking. Islamic Economic Studies, 27(2), 91-123.

25. Nurzaman, M. S.,Annisa, N.,\&Hendharto, R. G. (2017). Evaluation of the Productive Zakat Program of BAZNAS: A Case Study from Western Indonesia. International Journal of Zakat, 2(1), 81-93. https://doi.org/10.37706/ijaz.v2i1.17

26. PeraturanPemerintahRepublik Indonesia. (2014). PeraturanPemerintahRepublik Indonesia No. 14 Tahun 2014 
(pp. 1-46). pp. 1-46. Retrieved from https://peraturan.bpk.go.id/Home/Details/5451/pp-no-14-tahun-2014

27. PresidenRepublik Indonesia (2011). Undang-Undang Zakat No 23 Tahun 2011. Retrieved from https://kalteng.kemenag.go.id/file/file/GONDO/5121567496646.pdf

28. Rustyani, S.,\&Rosyidi, S. (2018). Measurement of Efficiency and Productivity of Zakat Institutions in Indonesia using Data Envelopment Analysis and the Malmquist Productivity Index. International Journal of Zakat, 3(3), 69-82. https://doi.org/10.37706/ijaz.v3i3.98

29. Sukesti, F.,\&Budiman, M. (2018). The Role of Zakat in Business Development of SMEs (Study on Baznas Semarang, Central Java, Indonesia). International Journal of Islamic Business Ethics, 3(1), 401-409. https://doi.org/10.30659/ijibe.3.1.401-409

30. Suprayitno, E. (2019). Zakat and SDGs: The Impact of Zakat on Economic Growth, Consumption and Investment in Malaysia. Advances in Economics, Business and Management Research, 101, $202-209$. https://doi.org/10.2991/iconies-18.2019.39

31. Tahir, M.,\&Triantini, Z. E. (2015). Integrasi Zakat danPajak di Indonesia dalamTinjauanHukumPositifdanHukum Islam. Al-'Adalah, 12(1),507-524.

32. Wahab, N.,Zainol, Z.,\& Bakar, M. (2016). Developing Service Quality Index for Zakat Institutions. Developing Service Quality for Zakat Institutions, 6(2012), 249-258.

33. Wahid, M. A. R. (2016). Integrasi Pajakdan Zakat di Indonesia Perspektif Hukum Islam dan Hukum Positif. Jurnal Ekonomi Islam,4(1), 27-58. https://doi.org/10.24090/ej.v4i1.2016.pp27-58 